\title{
REALITA MU'AMALAH: JUAL BELI SPERMA SAPI PADA PROGRAM PENYULUHAN DAN PEMBINAAN DI DESA KILANGAN KABUPATEN BATANGHARI
}

\author{
Iffah \\ Institut Agama Islam Nusantara Batanghari \\ Email: iffahsukses@gmail.com
}

\begin{abstract}
The goal of this study was to figure out what kind of program and processes animal caretakers use to counsel and guide cattle producers in Kilangan Village, Muara Bulian District, Batanghari Regency. This study is qualitative in nature. The author uses the interview method to gather the necessary information. There is a practice of buying and selling sperm at the Muara Bulian animal market, according to the practice of counseling and coaching. Based on the findings of the interview analysis, it can be inferred that in this practice, the farmer must pay a price if the artificial insemination is successful. The finding of the people's perception in Kilangan village opens our eyes to the fact that the jobs performed by government employees who have been paid an honorarium will also be rewarded when they respond to the needs of the people. Even the rates they are provided have an impact on their contract impression. It is called ijarah when the nominal amount offered is not determined by the mantri; nonetheless, the contract is made public by buying and selling, so modifying the law of the transaction; consequently, as a user community, it is important to comprehend the muamalah that is being carried out.
\end{abstract}

Keywords: Reality, Purchase and Selling, Artificial Insemination.

\begin{abstract}
Abstrak
Tujuan penelitian ini untuk mengetahui program dan prosedur penyuluhan dan pembinaan oleh mantri hewan terhadap peternak sapi di Desa Kilangan Kecamatan Muara Bulian Kabupaten Batanghari. Penelitian ini merupakan penelitian kualitatif. Penulis mengumpulkan data yang dibutuhkan dengan menggunakan metode wawancara. Dalam praktek penyuluhan dan pembinaan dipasar hewan Muara Bulian terindikasi ada praktek jual beli sperma. Hasil analisis dari wawancara tersebut dapat disimpulkan bahwa dalam praktek tersebut ada bayaran yang harus dikeluarkan peternak untuk keberhasilan inseminasi buatan tersebut. Penemuan persepsi masyarakat didesa Kilangan ini membuka mata kita bahwasanya tugas yang dijalankan oleh perangkat pemerintah yang sebetulnya sudah mendapatkan honorarium akan mendapatkan imbalan juga ketika sudah memenuhi panggilan masyarakat yang membutuhkan. Bahkan tarif yang diberikan mengubah persepsi mereka dalam hal akad. Jika nominal yang diberikan jumlahnya tidak ditentukan oleh mantri maka itu
\end{abstract}

Nur El-Islam, Volume 8, Nomor 1, April 2021 
disebut dengan ijarah, akan tetapi yang terjadi malah aqad tersebut dikenal masyarakat dengan jual beli, sehingga mengubah hukum transaksinya, oleh karena itu sebagai masyarakat pengguna sebaiknya memahami dengan baik muamalah yang sedang dijalani.

Kata kunci: Realita, Jual Beli, Inseminasi Buatan.

\section{A. Pendahuluan}

Globalisasi mengakibatkan perkembangan pesat pada teknologi canggih yang dapat kita lihat berimbas terhadap majunya teknologi pada bidang kedokteran. Salah satu dampak positif kemajuan teknologi yang dapat kita rasakan khususnya bagi peternak adalah inseminasi buatan pada hewan seperti sapi. Hal ini melatarbelakangi sangat maraknya terjadi jual beli sperma sapi (bank sperma). Menurut Abbas $^{1}$, jual beli sperma dilatarbelakangi oleh hal-hal berikut: “a) Keinginan memperoleh atau menolong untuk memperoleh keturunan pada seorang pasangan sapi yang tidak mempunyai anak; b) Memperoleh generasi jenius atau orang super; c) Menghindari kepunahan; d) Memilih suatu jenis kelamin; dan e) Mengembangkan kemajuan teknologi terutama dalam bidang kedokteran”.

Dalam pandangan bidang ilmu ekonomi, jual beli merupakan pemindahan hak milik barang atau aset yang mayoritas mempergunakan uang sebagai medium pertukaran. Ekonomi menjadi sesuatu yang sangat urgen bagi manusia, karena sumber daya ekonomi yang tidak tersedia atau bahkan tidak sebanding dengan kebutuhan manusia dan dunia bisnis sangat berpengaruh dalam hal tersebut. Bermuamalah juga merupakan bisnis, yang dianggap suatu proses untuk mencapai keuntungan dan mencukupi kebutuhan hidup. Etika bermu'amalah yang sesuai dengan syari'at Islam merupakan koridor bagi perkembangan ekonomi, karna manusia lebih mudah terlena dengan sistem ekonomi kapitalis yang bertujuan untuk mencari keuntungan yang sebesar-besarnya.

Jual beli merupakan pemindahan hak milik barang atau aset yang mayoritas mempergunakan uang sebagai medium pertukaran.

1 Suardi Abbas, Jual Beli Sperma dalam Perspektif Hukum Islam, https;/www.google.com/url?sa=t \&source=web \&rct=j \&url=https;//media.neliti.com 
Sama halnya dalam penyuntikan sperma hewan didesa Kilangan, peternak meminta jasa para mantri untuk menyuntikkan sperma ke hewan ternaknya atau sering disebut dengan kawin suntik (Inseminasi Buatan). Kawin suntik atau Inseminasi Buatan merupakan cara alternatif yang sering digunakan oleh peternak. Selain itu kawin suntik atau Inseminasi Buatan juga mengandung bibit hewan yang bagus. Setelah melakukan kawin suntik atau Inseminasi Buatan oleh mantri hewan, kemudian peternak memberikan upah kepada mantri hewan atas jasa yang telah dilakukannya. Hal ini terjadi karna untuk menghindari kerugian yang disebabkan sulitnya mengawinkan ternak sapi secara alami. Keberhasilan usaha pembibitan sapi salah satunya dapat diukur dari produksi jumlah kelahiran anak-anak sapi. Keberhasilan pengelolaan perkawinan sapi sangat ditentukan oleh bibit yang bagus, maka digunakanlah metode kawin suntik atau Inseminasi Buatan. Kawin suntik atau Inseminasi Buatan memiliki tujuan untuk meningkatkan mutu genetik ternak sehingga dapat melahirkan ternak-ternak yang berkualitas dengan produktivitas yang tinggi dan tahan terhadap suatu penyakit atau dapat mencegah penularan dan penyebaran penyakit kelamin, selain itu juga dapat meningkatkan angka kelahiran dengan cepat dan teratur serta dapat meningkatkan pendapatan peternak.

Sejak sistem kawin suntik atau inseminasi buatan mulai masuk kedalam masyarakat, sebagian masyarakat salah dalam memahami hukum dari kawin suntik ini. Karena pada umumnya masyarakat memberikan upah seperti halnya jual beli. Yang kemudian akan menimbulkan adanya jual beli yang dilarang dalam agama Islam. Belum terdapat kejelasan fatwa MUI dibolehkan atau tidaknya transaksi jual beli semen (sperma sapi) di desa Kilangan Kecamatan Muara Bulian Kabupaten Batanghari. Namun, inseminasi buatan diatur oleh Peraturan Bupati Batanghari Nomor 16 Tahun 2018. Dimana dalam peraturan tersebut inseminasi buatan merupakan salah satu kegiatan prioritas bidang pemberdayaan masyarakat desa. Berarti inseminasi buatan dilegalkan di desa Kilangan Kecamatan Muara Bulian Kabupaten Batanghari. 
Berdasarkan data yang diperoleh dari observasi yang ditemukan penulis dilapangan menemukan bahwa adanya jual beli sperma hewan yang dilarang dalam syari'at Islam. Namun masih banyak kurangnya pemahaman para masyarakat dalam jual beli sperma hewan tersebut. Sehingga pengelolaan sistem jual beli semacam ini disalah artikan dalam masyarakat. Tujuan penelitian ini untuk mengetahui program dan prosedur penyuluhan dan pembinaan oleh mantri hewan terhadap peternak sapi di Desa Kilangan Kecamatan Muara Bulian Kabupaten Batanghari, penelitian ini diharapkan berguna untuk menyampaikan realita muamalah dalam kehidupan sosial masyarakat yang terfokus dengan tema Jual Beli Sperma Sapi pada Program Penyuluhan dan Pembinaan di Pasar Hewan Muara Bulian Kabupaten Batanghari.

\section{B. Metodologi Penelitian}

Penelitian ini merupakan studi kualitatif deskriptif. Pengumpulan data pada penelitian ini dilakukan dengan metode wawancara. Menurut Sugiyono ${ }^{2}$ teknik pengumpulan data dengan menggunakan wawancara dilakukan jika peneliti ingin melakukan studi pendahuluan untuk menemukan masalah yang diteliti, mencari data yang mendalam dengan jumlah responden sedikit/kecil. Pada kegiatan wawancara maka subjek dianggap yang paling tahu tentang dirinya, data yang diberikan oleh subjek adalah benar, interpretasi subjek tentang pertanyaan yang diajukan peneliti adalah sama dengan apa yang dimaksud oleh peneliti. Analisis data penelitian kualitatif menurut Miles dan Huberman dalam Sugiyono $^{3}$ dapat dilakukan dengan cara data reduction, data display, dan conclusion drawing/verification. Mereduksi data berarti merangkum dan memfokuskan pada hal-hal yang penting. Display data dapat dilakukan dengan membuat teks naratif, grafik, matrik, network, dan chart. Sedangkan conclusion drawing/verification dilakukan dengan membuat kesimpulan dengan menjawab rumusan masalah yang telah dirumuskan sebelumnya.

${ }^{2}$ Sugiyono, Metode Penelitian Pendidikan, Bandung: Alfabeta, 2015.

${ }^{3}$ Ibid. 
Sumber data lapangan didapat dari seorang mantri hewan, peternak, ketua pasar, dan sebagainya yang merupakan sumber data primer. Metode observasi digunakan penulis untuk mencari data yang sebenarnya serta tidak hanya direkayasa sesuai dengan kutipan. Teknik pengumpulan dengan metode observasi digunakan bila penelitian berkenaan dengan prilaku manusia, proses kerja, gejalagejala alam dan bila reponden yang diamati terlalu besar. Langkah selanjutnya melalui wawancara terstruktur dan sistematis dengan sumber data primer didapatkan informasi yang valid. Langkah terakhir adalah uji dokumentasi, data yang telah tersedia dalam bentuk dokumen disandingkan dengan data baru yang terkumpul untuk melihat kesenjangan teori dan realita yang terjadi dimasyarakat.

\section{Pembahasan}

1. Temuan Penelitian

a. Pengertian Mu'amalah: Jual Beli Sperma Sapi

Mu'amalah menurut kamus lengkap ekonomi Islam berarti transaksi-transaksi, hukum-hukum yang mengatur hubungan antar manusia. ${ }^{4}$ Jual beli secara etimologi adalah pertukaran sesuatu dengan sesuatu (yang lain). ${ }^{5}$ Terminologi mengatakan bahwa jual beli merupakan persetujuan saling mengikat antara penjual dan pembeli. ${ }^{6}$

"Jual beli merupakan suatu perjanjian tukar menukar barang atau benda yang memiliki nilai, secara sukarela diantara kedua belah pihak, yang satu menerima benda dan pihak lainnya menerima uang sebagai kompensasi barang, dan sesuai dengan perjanjian atau ketentuan yang telah dibenarkan syarā' dan disepakati”. ${ }^{7}$

Para ulama berbeda pendapat dalam mendefinisikan pengertian jual beli, diantaranya: ${ }^{8}$

\footnotetext{
2009.

${ }^{4}$ Dwi Suwikyo, Kamus Lengkap Ekonomi Islam, Jakarta Selatan: PT. Buku Kita,

${ }^{5}$ Sri Sudiarti, Fiqh Muamalah Kontemporer, Medan: FEBI UIN-SU Press, 2018.

${ }^{6}$ Ibid.

${ }^{7}$ Masjupri, Fiqh Muamalah 1, Surakarta: FSEI Publishing, 2013.

${ }^{8}$ Sri Sudiarti, Fiqh Muamalah Kontemporer, h. 74-75.
} 
Menurut ulama Hanafiah jual beli terdapat dua pengertian. Pertama, bersifat khusus, yaitu menjual barang dengan mata uang (emas dan perak). Kedua, bersifat umum, yaitu pertukaran benda dengan benda menurut ketentuan tertentu. Benda disini dapat diartikan barang dan mata uang, sedangkan sifat-sifat dari benda tersebut harus dapat dinilai, yaitu benda-benda yang berharga dan dapat dibenarkan penggunaannya menurut syarā'. Sedangkan menurut ulama Malikiyah jual beli terdapat dua pengertian. Pertama, bersifat umum, yaitu transaksi tukar menukar suatu yang bukan kemanfaatan dan kenikmatan. Maksudnya yaitu ikatan yang mengandung pertukaran dari kedua belah pihak (penjual dan pembeli), yakni salah satu pihak menyerahkan ganti penukaran atas sesuatu yang ditukarkan oleh pihak lain. Jual beli dalam arti khusus adalah ikatan tukar-menukar sesuatu yang bukan manfaat dan kelezatan yang mempunyai daya penarik, salah satu pertukarannya bukan berupa emas dan perak yang dapat direalisasikan bendanya, bukan ditangguhkannya. Sementara itu menurut ulama Syafi'iyyah jual beli adalah pertukaran harta dengan harta dalam segi tertentu, yatiu suatu ikatan yang mengandung pertukaran harta dengan harta yang dikehndaki dengan tukar menukar, yaitu masing-masing pihak menyerahkan prestasi kepada pihak lain baik sebagai penjual maupun sebagai pembeli. Menurut ulama Hanabilah jual beli adalah pertukaran harta dengan harta atau manfaat dengan manfaat lain yang dibolehkan secara hukum dan pemberian manfaat tersebut bukan riba serta bukan bagi hasil.

Berdasarkan uraian beberapa pengertian tersebut dapat disintesiskan bahwa mu'amalah jual belisperma sapi merupakan transaksi pertukaran antara sperma sapi dengan benda yang sebanding nilainya antara orang perorangan atau orang dengan sekelompok orang dengan syarat sesuai ketentuan yang telah disepakati. Kegiatan muamalah yang disyariatkan oleh Allah SWT terdapat pada Q.S. Al-Baqarah ayat 275 dan An-nisa ayat 29. Ayat-ayat 
Alqur'an tersebut merupakan dalil diperbolehkannya jual beli dan menunjukkan betapa Alqur'an memberikan kepedulian besar terhadap jual beli. Dalam surat An-nisa ayat 29 menjelaskan bahwa Allah telah mengharamkan memakan harta orang lain dengan cara bathil yaitu tanpa ganti dan hibah, yang demikianitu adalah batil berdasarkan ijma dan termasuk didalamnya juga semua jenis akad yang rusak yang tidak dibolehkan oleh syarā' baik karena ada unsur riba atau jahalah (tidak diketahui). ${ }^{9}$

Landasan hukum jual beli dalam Al-quran jelas di halalkan, namun pada rukun dan syarat para fuqaha berbeda pendapat, bahkan untuk hal yang bersifat kontemporer pembahasan makin meluas dan metode istinbath semakin berkembang, sebagai contoh imama asySyafi'i yang mensyaratkan jual beli harus bukan benda yang najis, bukan benda yang belum jelas artinya ada batasan yang menyertai kebolehan jual beli tersebut. Para ulama berpendapat bahwa hukum asal jual beli adalah mubah atau jawaz (boleh) apabila terpenuhinya syarat dan rukunnya. Akan tetapi pada situasi tertentu, hukum jual beli bisa berubah menjadi wajib, haram, mandub dan makruh. Berikut contoh-contohnya. ${ }^{10}$

“a) Jual beli wajib: apabila seseorang terdesak untuk membeli makanan atau yang lain, maka penjual tidak boleh menimbunnya atau tidak menjualnya; b) Jual beli haram: memperjualbelikan barang yang haram menurut hukum syarā', seperti jual beli anjing, babi, dan lainnya; c) Jual beli nadb (sunnah): seorang penjual bersumpah kepada orang lain akan menjual barang dagangannya, yang tidak akan menimbulkan kemudharatan bilamana ia menjualnya; d) Jual beli makruh: memperjualbelikan kucing dan kulit binatang buas untuk dimanfaatkan kulitnya".

“Menurut jumhur ulama, rukun jual beli, yaitu: a) Akad (ijab qabul) adalah ikatan kata antara penjual dan pembeli. Ijab qabul bisa

${ }^{9}$ Abdul Rahman Ghazaly, Fiqh Muamalat, Jakarta: Predana Media Group, 2010.

${ }^{10}$ Enang Hidayat, Fiqh Jual Beli, Bandung: PT. Remaja Rosdakarya, 2015. 
dilakukan dengan ucapan atau tulisan. Menurut fatwa ulama Syafi'iyah, jual beli barang yang kecilpun harus terdapat ijab qabul, tetapi menurut Imam an-Nawawi dan ulama muta'akhirin syafi'iyah berpendapat bahwa jual beli yang kecil boleh tidak dengan ijab qabul; b) terdapat orang yang berakad yaitu bay' (penjual) dan mustari (pembeli); c) Maqud 'alaih (objek), yaitu barang yang bermanfaat menurut syarā'; d) ada nilai tukar pengganti barang, yaitu sesuatu yang memenuhi tiga syarat yakni bisa menyimpan nilai, bisa menilai atau menghargakan suatu barang dan bisa dijadikan alat tukar". ${ }^{11}$

"Syarat jual beli menurut para ulama: a) syarat yang berhubungan dengan dua orang yang berakad yaitu penjual dan pembeli: 1) Mumayyiz, baligh dan berakal. Maka tidak sah akadnya orang gila, orang yang mabuk, anak kecil, kecuali dengan izin walinya; 2) tidak terlarang membelanjakan harta, baik terlarang itu hak dirinya atau yang lainnya; 3) tidak terpaksa dalam melakukan akad. Maksudnya yaitu harus adanya kerelaan dari kedua belah pihak yang merupakan salah satu rukun jual beli; b) syarat yang berhubungan dengan ma'qud 'alayh/tsaman dan mutsman (nilai tukar pengganti barang dan barang yang diperjualbelikan), para ulama menyepakati tiga syarat: 1) Harta yang diperjualbelikan itu harta yang dipandang sah oleh agama; 2) Harta yang diperjualbelikan itu dapat diketahui oleh penjual dan pembeli; 3) Harta yang diperjualbelika itu tidak dilarang oleh agama; c) syarat yang berkaitan dengan sighat (ijab dan qabul): 1) Ijab qabul diungkapkan dengan kata-kata yang menunjukkan jual beli yang biasa diketahui masyarakat. Contohnya penjual berkata: “Aku jual bolpoin ini kepadamu seharga Rp. 20.000,-. Kemudian pembeli menjawab: "Saya beli bolpoin ini seharga Rp. 20.000,-. Apabila ijab qabul tidak sesuai maka jual beli tidak sah; 2) Ijab qabul dilaksanakan dalam satu majelis. Artinya kedua belah pihak bertemu dan membicarakan topik jual beli tersebut; 3) terdapat kesepakatan berkenaan dengan barang, baik jenis, macamnya, sifatnya

${ }^{11}$ Waluyo, Fiqih Muamalat, Yogyakarta: CV Gerbang Media Aksara, 2014. 
dan juga harganya barang yang diperjualbelikan, baik tunai atau tidaknya". ${ }^{12}$

"Macam-macam jual beli: a) Pembagian jual beli berdasarkan objek barangnya: 1) Muqa'iazah yakni jual beli barang dengan barang; 2) Sharf yakni jual beli tunai dengan tunai, seperti emas dengan perak; 3) Salam yakni jual beli dengan penyerahan barang di belakang. Seperti pembelian gandum yang masih diladangnya; 4) Mutlaq yakni jual beli bebas barang dengan uang; b) Jual beli berdasarkan batasan nilai tukar: 1) Bay' al-Musawamah, yaitu jual beli dimana penjual tidak menyebutkan harga asal barang; 2) Bay' al-Muzayadah, yaitu penjual memberitahu harga di pasar terlebih dahulu kemudian pembeli membeli barang tersebut dengan harga yang lebih tinggi dari harga asal; 3) Bay' al-Amanah, yaitu penjualan yang harganya dibatasi dnegan harga awal atau ditambahi atau dikurangi. Contohnya, "saya membeli barang ini dengan harga Rp. 100.000,- dan sekarang saya jual barang ini kepada anda dengan harga RP. 130.000"; c) Jual beli berdasarkan penyerahan nilai tukar penganti barangnya: 1) Bay' Munjiz al-Tsaman, jual beli yang syarat pembayarannya harus tunai; 2) Bay’ Muajjal al-Tsaman, yaitu jual beli yang serupa dengan bay' alsalam; 3) Bay' Muajjal al-Mutsman, yaitu jual beli yang serupa dengan bai' al-salam; 4) Bay' Muajjal al- 'Iwadhain, yaitu jual beli utang dengan utang. Jual beli ini dilarang oleh syarā'; d) jual beli berdasarkan hukumnya: 1) Bay' al-Mn'aqid lawannya bay' al-batil, jual beli yang diperbolehkan oleh syarā'; 2) Bay' al-Shahih lawannya bay' al-fasid, yaitu jual beli yang terpenuhi syarat sahnya; 3) Bay' al-Nafidz lawannya bay' al-mauquf, yaitu jual beli shahih yang dilakukan oleh orang yang cakap melaksanakannya seperti baligh dan berakal; 4) Bay' al-Lazim lawannya bay' gair al-lazim, yaitu jual beli shahih yang sempurna dan tidak ada hak khiyar didalamnya". ${ }^{13}$

"Jual beli yang dilarang dalam Islam: a) jual beli yang diharamkan karena garar dan jahalah: 1) Bay' al-Munabadah: jual beli ini dengan cara lempar melempar; 2) Bay' al-Mulamasah: jual beli ini

${ }^{12}$ Enang Hidayat, Fiqh Jual Beli, h. 20.

${ }^{13}$ Ibid. h. 49. 
saling menyentuh; 3) Bay’ al-Hasah; 4) Bay’ Habl al-Habalah: jual beli janin yang masih dalam kandungan induknya; 5) Bay' al-Madamin dan Bay' al-Malaqih: jual beli ini adalah menjual sperma yang berada dalam sulbi unta jantan; 6) Bay' 'asab al-Fahl: jual beli sperma hewan pejantan; 7) Bay' al-Tamar Qabla Badawwi Shalahiha: jual beli buahbuahan sebelum masak; 8) Bay' al-Sanaya: penjualan yang pengecualiannya disebut secara samar (kabur, tidak jelas); 9) Bay'ma Laisa 'Indahu: jual beli sesuatu yang belum menjadi hak miliknya". ${ }^{14}$

"Jual beli yang dilarang karena zatnya (haram Iidzatihi): 1) Bay" al-Maitah: binatang yang mati dengan cara yang tidak disembelih (bangkai); 2) Jual beli arak (khamr): setiap minuman yang memabukkan yang terbuat dari perasan anggur, adapun selain terbuat dari perasan anggur disebut nabiz; 3) Jual beli anjing: hukumnya tidak diperbolehkan secara mutlak, sekalipun anjing yang terlatih; 4) Jual beli babi: babi termasuk benda najis dan tidak dipandang sebagai benda yang dimanfaatkan dan juga karena adanya nash sharih yang menjelaskan dilarangnya jual beli babi; 5) Jual beli darah: darah yang masih terdapat pada binatang yang masih hidup dan juga binatang yang haram dimakan walaupun disembelih".

Jual beli yang sah tetapi dilarang: 1) membeli barang dengan harga yang lebih mahal dari pada harga pasar, sedangkan dia tidak menginginkan barang tersebut; 2) membeli barang yang sudah dibeli orang lain yang masih dalam masa khiyar; 3) mencegat orang-orang yang datang dari desa di luar kota untuk berdagang kemudian membeli barang dagangan tersebut sebelum itu sampai ke pasar dan sewaktu pedagang belum mengetahui harga pasar; 4) membeli barang untuk ditahan agar dapt dijual dengan harga yang lebih mahal, sedangkan masyarakat umum membutuhkan barang tersebut; 5) menjual barang yang bermanfaat akan tetapi barang tersebut dijadikan alat maksiat oleh pembelinya; dan 6) jual beli yang mengandung unsur penipuan. ${ }^{15}$

${ }^{14}$ Ibid, h. 116.

${ }^{15}$ Sulaiman Rasjid, Fiqh Islam, Bandung: Sinar Baru Algesindo, 1994. 
b. Inseminasi Buatan

Inseminasi Buatan (IB) berasal dari kata artificial inseminator (Inggris) kunstmatige inseminatie (Belanda). Insemination articielle (Prancis), atau Kunstliche besamung (Jerman). Artificial artinya tiruan atau buatan. Sedangkan insemination berasal berasal dari kata latin inseminatus'in artinya pemasukan, penyampaian atau deposisi sedangkan semen adalah cairan yang mengandung sel-sel kelamin jantan yang diejakulasikan melalui penis pada waktu kopulasi atau penampungan. Jadi, menurut definisi Inseminasi Buatan (IB) adalah pemasukan atau penyampaian semen kedalam saluran kelamin betina dengan menggunakan alat-alat buatan manusia, jadi bukan secara alam, atau suatu cara atau teknik untuk memasukan mani (sperma atau semen) yang telah dicairkan dan telah diproses terlebih dahulu yang berasal dari ternak jantan kedalam saluran alat kelamin betina dengan menggunakan metode dan alat khusus yang disebut insemination gun. ${ }^{16}$

Inseminasi buatan (IB) (artificial insemination) ialah pembuahan pada hewan atau manusia melalui senggama. Masalah inseminasi buatan (IB) ini menurut pandangan islam termasuk dalam masalah ijtihadi, karena tidak terdapat didalam al-Quran dan Sunah. Oleh karena itu kalau masalah ini hendak dikaji menurut hukum Islam. Masalah inseminasi buatan (IB) ini sejak tahun 1980an telah banyak dibicarakan dalam Islam, baik ditingkat nasional maupun tingkat internasional. ${ }^{17}$ Tujuan inseminasi buatan, yaitu: 1) memperbaiki mutu genetika ternak; 2) tidak harus pejantan unggul untuk dibawa ketempat yang dibutuhkan sehingga mengurangi biaya; 3) mengoptimalkan penggunaan bibit pejantan unggul secara lebih luas dalam jangka waktu yang lebih lama; 4) meningkatkan angka kelahiran dengan cepat dan teratur; 5) mencegah penularan/penyebaran penyakit menular. ${ }^{18}$

\footnotetext{
${ }^{16}$ Feradis, Bioteknologi Reproduksi pada Ternak, Bandung: Alfabeta, 2010.

${ }^{17}$ Masjfuk Zuhdi dan Masail Al-Fikiyah, Kapita Selekta Hukum Islam, Jakarta: Masagung, 1994., cet ke-8, h. 152.

${ }^{18}$ Ibid. h. 16.
} 
Manfaat inseminasi buatan: 1) IB mempertinggi penggunaan pejantan-pejantan yaitu daya guna seekor pejantan yang genetiknya unggul dapat dimanfaatkan semaksimal mungkin; 2) dapat menghemat biaya; 3) penyeleksian yang teliti terhadap pejantan; 4) penularan penyakit dapat dicegah sehingga pejantan-pejantan bebas dari penyakit; dan 5) dapat meneruskan pemakaian pejantan-pejantan tua. ${ }^{19}$ Dalam hadits Bukhari, no. 2284 menjelaskan tentang larangan sperma hewan: Artinya: Dari Ibnu Umar radhiallahu 'anhuma, dia berkata, Nabi shallallahu 'alaihi wa sallam melarang sperma pejantan. ${ }^{20}$ Hadits tersebut menjelaskan, dalam kata "melarang sperma pejantan" maksudnya adalah tentang jual beli sperma dan uang sewa karena mengawinkan sapi betina dengan sapi jantannya. Sebab diharamkannya karena sperma merupakan barang yang tidak bisa diukur, tidak diketahui, kadar jumlahnya dan tidak bisa diserahkan. Selain itu alasan pengharaman karena objek transaksi (yaitu, sperma pejantan) itu tidak bisa diserahkan, karena keluarnya sperma pejantan itu sangat tergantung dengan keinginan dan syahwat pejantan.

c. Program dan Prosedur Penyuluhan dan Pembinaan oleh Mantri Hewan terhadap Peternak Sapi di Desa Kilangan Kecamatan Muara Bulian Kabupaten Batanghari

Sering kali ekonomi menjadi masalah yang serius bagi manusia, karena sumber daya ekonomi yang tidak tersedia atau bahkan tidak sebanding dengan kebutuhan manusia dan dunia bisnis sangat berpengaruh dalam hal tersebut. Bermuamalah juga merupakan bisnis, yang dianggap suatu proses untuk mencapai keuntungan dan mencukupi kebutuhan hidup. Etika bermu'amalah yang sesuai dengan syari'at Islam perlu diterapkan, karena manusia lebih mudah terlena dalam bermu'amalah yang bertujuan untuk mencari keuntungan yang sebesar-besarnya. Dalam hal ini, pedagang sering kali lupa akan kedudukan yang tinggi dan pahala yang sangat besar yang telah h. 24.

${ }^{19}$ Mozes R. Toelihere, Inseminasi Buatan pada Ternak, Bandung: Angkasa, 1979,

${ }^{20}$ Muhammad Fuad Abdul Baqi, Terjemah Shahih Al-Bukhari (jilid 2) (Jakarta: Pustaka As-Sunnah, 2010), h. 528 
dijanjikan Allah SWT bagi para pedagang yang jujur, amanah, tidak rakus dan tidak tamak. Apa yang dilakukan Rasulullah SAW dimasa hidupnya sudah cukup jelas bagi kita. Sebagaimana beliau memberikan perhatian pada bidang ekonomi, dengan didirikannya pasar yang Islami dan mandiri.

Peternak yang ingin mengawinkan ternaknya secara kawin suntik atau inseminasi buatan biasanya menghubungi mantri untuk datang ke rumah. Maka mantri akan datang membawa sperma dan alat-alat untuk melakukan suntik kawin tersebut. Sebelum melakukan suntik kawin atau IB biasanya mantri akan memeriksa keadaan hewan ternak terlebih dahulu. Apabila hewan ternak tersebut sedang dalam birahi atau tidak. Namun biasanya para peternak sudah memahami keadaan tersebut. Ketika keadaan hewan sudah birahi maka peternak akan memanggil mantri untuk datang kerumah. ${ }^{21}$ Proses inseminasi Buatan terkadang juga mengalami kegagalan karena beberapa faktor, seperti ternak terlalu stres. Kemudian setelah mereka menyelesaikan inseminasi buatan maka mereka diberi uang sebagai upah (Ijarah) atas pekerjaanya. Namun, ada juga mantri yang mentarifkan uang tersebut seperti mantri baru atau mantri magang. Ketika berhasil atau tidaknya maka peternak akan tetap membayar senilai Rp. 150.000.

Ijarah berarti upah atau ganti atau imbalan. Pengertian umum dari ijarah mempunyai jasa atau pemanfaatan sesuatu benda atau imbalan sesuatu kegiatan, atau upah karena melakukan sesuatu aktifitas. ${ }^{22}$ Menurut terminologi ijarah adalah menjual manfaat. Ijarah menurut ulama Hanafiah, ijarah artinya akad atas suatu kemanfaatan dengan pengganti. Ulama Syafiyah, mengemukakan ijarah sebagai akad suatu kemanfaatan yang mengandung maksud tertentu dan mubah, serta menerima pengganti atau kebolehan dengan pengganti tertentu. Menurut Ulama Malikiah dan Hanafiah, ijarah artinya menjadikan milik suatu kemanfaatan yang mubah dalam waktu tertentu dengan pengganti. ${ }^{23}$

\footnotetext{
${ }^{21}$ Ahmad, Wawancara, 2 April 2019, Desa Kilangan

${ }^{22}$ Helmi Karim, Fiqh Muamalah, Jakarta: PT. Raja Grafindo Persada, 1993, cet ke-

${ }^{23}$ Rachmat Syafi'I, Fiqh Muamalah, Bandung: Pustaka Setia, 2001, h. 21.
} 1, h. 29. 
Berdasarkan uraian pendapat di atas, dapat disintesiskan bahwa ijarah merupakan pengambilan manfaat terhadap suatu barang atau jasa yang melibatkan seseorang dengan orang lain sesuai dengan jangka waktu yang telah ditentukan dan adanya imbalan atau upah serta tanpa adanya pemindahan kepemilikan. Hal ini didukung oleh pernyataan Sudiarti yang mengungkapkan bahwa ijarah adalah sewa menyewa yang jelas manfaat dan tujuannya, dapat diserahterimakan, boleh dengan ganti (upah) yang telah diketahui, seperti rumah untuk ditempati, mobil untuk dinaiki, dan jasa mantri yang melakukan inseminasi buatan. ${ }^{24}$

Ijarah membutuhkan adanya orang yang memberi jasa dan yang memberi upah. Ijarah yaitu mengupahkan seseorang dalam tugas sesuatu misalnya untuk mengajari anak-anak membaca Al qur'an dan hukumnya boleh. ${ }^{25}$ Adapun rukun Ijarah yaitu: 1) Mu'jir (orang yang memberikan upah dan yang menyewakan) dan Musta'jir (orang yang menerima upah untuk melakukan sesuatu atau yang menyewa sesuatu; 2) Shighat ijab kabul, ijab kabul sewa menyewa misalnya: aku sewakan mobil ini kepadamu setiap harga Rp. 5000,00 maka musta'jir menjawab aku terima sewa mobil tersebut dnegan harga demikian setiap hari. Ijab kabul upah mengupah misalnya seseorang berkata, kuserahkan kebun kepadamu untuk dicangkul dengan upah setiap hari Rp. 5000,00 kemudian musta'jir menjawab aku akan kerjakan pekerjaan sesuai dengan apa yang engkau ucapkan; 3) Ujrah (upah), disyaratkan dketahui jumlahnya oleh kedua belah pihak baik dalam sewa menyewa maupun dalam upah mengupah, dasarnya adalah besarnya manfaat yang dibenarkan oleh pekerjaan tersebut; 4) barang yang disewakan atau sesuatu yang dikerjakan dalam upah mengupah. 26

Ekonomi Islam juga memerlukan landasan kebijakan pembangunan ekonomi guna mengarahkan kepada jalan yang benar, seperti landasan tauhid dan keadilan serta Istimrariyyah

\footnotetext{
${ }^{24}$ Sri Sudiarti, Fiqh Muamalah Kontemporer, h. 194.

${ }^{25}$ Sudarsono, Pokok-pokok Hukum Islam, Jakarta: PT. Rineka Cipta, 1993, cet ke-1, h. 422 . ${ }^{26}$ Ibid. 118.
} 
(berkelanjutan atau pelestarian). ${ }^{27}$ Dengan dipublishnya tulisan ini bertujuan agar segala aktifitas muamalah yang kita jalani berada dalam koridor syari'ah seperti kasus pemberian imbalan atau tarif kepada mantri hewan yang memberikan suntikan inseminasi buatan didesa kilangan ini.

\section{d. Beberapa Kajian Terdahulu pada Beberapa Tempat Berbeda}

Penelitian pertama mengenai 'Urf Jual Beli Sperma Hewan dengan studi kasus di desa Batealit Kabupaten Jepara yaitu dengan membayar sejumlah uang atau upah (ijarah) kepada petugas inseminasi buatan (IB). Selain itu ada pula Penelitian yang membahas mengenai tentang penilaian praktik jual beli sperma hewan ternak studi kasus di Desa Bigaran sesuai atau tidaknya dengan ketentuan jual beli dalam hukum Islam. Penelitian ketiga membahas mengenai Pandangan Tokoh Agama Terhadap Praktik Jual Beli Sperma Hewan, studi kasus di Desa Saba Kecamatan Janapria Kabupaten Lombok Tengah. Sedangkan penelitian yang penulis buat membahas mengenai hukum jual beli sperma hewan dan upah dari Jual Beli Sperma Hewan dengan studi kasus di Desa Kilangan.

Penelitian terdahulu yang juga mendukung penelitian ini dilakukan oleh Deni Setiyono ${ }^{28}$. Dimana hasil penelitiannya mengungkapkan bahwa Imam Maliki dan Imam Syafi'i membolehkan menyewa untuk mengawinkan hewan dalam waktu tertentu dan dalam peminjaman ini menghadiahkan sesuatu kepada orang yang memberi pinjaman itu diperbolehkan tetapi tanpa syarat tertentu. Namun, terdapat perbedaan diantara ulama tersebut. Menurut Imam Maliki seseorang menyewakan binatang pejantan untuk dikawinkan beberapa kali selama satu hari atau dua hari dengan hewan betina agar bisa hamil untuk mendapatkan keturunan hewan dari hewan pejantan tersebut. Masalah ini termasuk maslahah mursalah, seandainya

${ }^{27}$ Ija Suntana, Politik Ekonomi Islam Siyasah Maliyah (Bandung: Pustaka Setia, 2010), hal. 16-17

${ }^{28}$ Deni setiyono, Upah Mengupah Mengawinkan Hewan Ternak dalam Pandangan Imam Maliki dan Syafi'i (Studi dusun 8 Desa Sendang Ayu Kec. Padang Ratu Kabupaten Lampung Tengah). Undergraduate Thesis, UIN Raden Intan Lampung, 2018. 
dilarang niscaya akan terputus perkembangbiakan. Sedangkan menurut Imam Syafi'i upah mengawinkan hewan ternak tidak dibolehkan karna air mani atau sperma tidak dapt diketahui kadarnya, lagi pla tidak dapt diterima beberapa kadar air mani tersebut dikarenakan adanya gharar karena tidak jelas zat, sifat dan ukuran sperma yang tidak mampu diserahterimakan.

Penelitian berikutnya yang mendukung kajian penelitian ini dilakukan oleh Ahmad Barozah. ${ }^{29}$ Hasil penelitiannya mengungkapkan bahwa jual beli sperma hewan dalam proses IB yang terjadi di desa Bigaran dilakukan dengan alasan untuk menghindari kerugian yang disebabkan sulitnya mengawinkan ternak sapi secara alami. Dengan kemudahan serta unggulnya bibit yang dihasilkan dari proses IB maka peternak lebih mendapatkan manfaat dari jual beli sperma beku (strow). Jual beli sperma beku (strow) telah sesuai dengan kaidah fikih yaitu mendatangkan manfaat dan menghindari mudharat. Sperma beku telah diolah sedemikian rupa sehingga adanya kejelasan dan jaminan kepastian terhadap keberhasilan inseminasi, sperma beku telah sesuai dengan syarat-syarat obyek akad dalam hukum Islam. Dengan demikian, praktik jual beli sperma beku dalam inseminasi buatan diperbolehkan menurut Islam.

Penelitian lain yang juga mendukung kajian penelitian ini yaitu penelitian yang dilakukan oleh Suardi Abbas. ${ }^{30}$ Penelitiannya mengungkapkan bahwa: 1) Jual beli sperma masih menjadi kontroversi ulama namun pendapat yang dapat dijadikan pegangan dan pedoman bagi kita bahwa menjual sperma hukumnya haram baik manusia atau hewan sebab sperma tidak layak diperjualbelikan dan faktor-faktor penghalang sebagaimana dilihat dari keumuman hadits bahwa Rasulullah melarang jual beli sperma; dan 2) Bank sperma adalah pengambilan sperma dari donor sperma lalu dibekukan dan disimpan ke dalam larutan nitrogen cair untuk mempertahankan fertilitas

${ }^{29}$ Ahmad Barozah, Tinjauan Hukum Islam terhadap Jual Beli Sperma Hewan Ternak di Desa Bigaran Borobudur magelang, Skripsi Thesis, UIN Sunan Kalijaga Yogyakarta, 2011.

30 Suardi Abbas, Jual Beli Sperma dalam Perspektif Hukum Islam, https;//www.google.com/url?sa=t\&source=web\&rct=j\&url=https;//media.neliti.com 
sperma. Adapun mengenai status anak hasil inseminasi buatan dengan donor sperma dan/atau ovum menurut hukum Islam adalah tidak sah dan statusnya sama dengan anak hasil prostitusi atau hubungan perzinaan. Keinginan memperoleh atau menolong untuk memperoleh keturunan pada seorang pasangan suami isteri yang tidak mempunyai anak. Memperoleh generasi jenius atau orang super. Menghindarkan kepunahan manusia, memilih suatu jenis kelamin, serta mengembangkan kemajuan teknologi terutama dalam bidang kedokteran.

\section{Pembahasan}

Salah satu praktek ekonomi Islam yang sangat dekat dalam kehidupan manusia adalah al-Bay'. al-bay atau' Jual beli menurut bahasa berarti memindahkan hak milik terhadap benda dengan akad saling mengganti. Dikatakan Ba'a asy-syaia jika ia mengeluarkannya dari hak miliknya, dan ba'ahu jika dia membelinya dan memasukkannya ke dalam hak miliknya. Dalam terminologi syara', jual beli berarti "Akad saling mengganti dengan harta yang berakibat kepada kepemilikan terhadap satu benda atau manfaat untuk tempo waktu selamanya dan bukan untuk bertaqarrub. Dari definisi ini terlihat bahwa jual beli merupakan akad yang mempunyai sifat saling tukar menukar, yaitu menukar satu harta dengan harta yang lain. Namun perkembangan zaman telah semakin pesat, sehingga sekarang tukar menukar atau jual beli sudah menggunakan nilai tukar yaitu berupa uang. Jual beli merupakan perkara yang sering dilakukan dalam masyarakat. Maka dari itu jual beli merupakan jual beli yang harus sesuai dengan syari'at islam, baik dari jenis barang yang dijual, asal mula barang tersebut dan bagaimana cara menjualnya serta dalam melakukan akad. Tidak lepas pula jual beli harus memenuhi syarat dan rukun, baik pada pembeli, penjual, barang maupun ijab dan qabul. Allah SWT telah mensyaria'atkan jual beli, menganjurkan dan menjadikannya sebagai salah satu cara untuk mendapatkan rahmat Allah SWT. Begitu bernilainya harta bagi kehidupan manusia, AlQur'an juga memberikan batasan-batasan umum dalam bermuamalah, salah satunya larangan memakan harta secara batil. Hal ini menjadi 
bukti bahwa Islam memiliki etika bagaimana melindungi hak dan kekayaan orang lain agar tidak dilanggar dan dirampas. Sebagaimana dalam Al-Qur'an, yang merupakan sumber utama dan pertama ajaran Islam. Ajaran Islam ditandai dengan sistem ajarannya yang menyentuh semua aspek kehidupan manusia. Termasuk didalamnya ajaran tentang ekonomi dan keuangan. ${ }^{31}$ Jenis benih hewan ternak dengan menggunakan Inseminasi Buatan tidak dapat diketahui, apakah itu betina atau pejantan. Jika para peternak ada yang meminta suntik kawin atau Inseminasi Buatan dengan benih pejantan, para mantri tidak bisa menjaminnya. Jika ada peternak yang meminta khusus jenis benih sperma jantan, hal tersebut tidak disediakan pemerintah. Yang artinya hal tersebut diluar tanggung jawab pemerintah, karna pemerintah hanya menyediakan sperma dengan jenis yang tidak bisa ditentukan. Permintaan tersebut jarang terjadi atau bahkan belum ada sistem tersebut di Muara Bulian, karna para mantri tidak ingin mengambil resiko, dimana ketentuan jenis benih hanya Allah Ta'ala yang bisa menghendakinya. Selain itu biaya untuk permintaan khusus seperti itu sangatlah mahal dan para mantri tidak ingin membebani peternak dengan hal tersebut, serta untuk mendapatkan jenis benih khusus tersebut didapatkan dari tempat jauh seperti dari jawa. ${ }^{32}$

Dari kasus ini dimungkinkan akan terjadi temuan-temuan tak terduga. Seperti contoh pengaruh ternak yang mengalami kawin suntik terhadap perkembangan ekonomi pada lingkungan peternak tersebut atau mungkin perubahan sifat hewan dari hasil kawin suntik. Penemuan persepsi masyarakat didesa Kilangan ini membuka mata kita bahwasanya tugas yang dijalankan oleh perangkat pemerintah yang sebetulnya sudah mendapatkan honorarium akan mendapatkan imbalan juga ketika sudah memenuhi panggilan masyarakat yang membutuhkan. Bahkan tarif yang diberikan mengubah persepsi mereka dalam hal akad. Jika nominal yang diberikan jumlahnya tidak ditentukan oleh mantri maka itu disebut dengan ijarah, akan tetapi

\footnotetext{
${ }^{31}$ Muhammad Amin Suma, hal. 50

${ }^{32}$ Lutfi, Wawancara, 5 April 2019, Pasar hewan di Muara Bulian
} 
yang terjadi malah aqad tersebut dikenal masyarakat dengan jual beli, sehingga mengubah hukum transaksinya, oleh karena itu sebagai masyarakat pengguna sebaiknya memahami dengan baik muamalah yang sedang dijalani.

\section{Penutup}

Praktek penyuluhan dan pembinaan dipasar hewan Muara Bulian terindikasi terdapat praktek jual beli sperma. Dalam praktek tersebut ada bayaran yang harus dikeluarkan peternak untuk keberhasilan inseminasi buatan tersebut.

\section{Daftar Pustaka}

Abdul Rahman Ghazaly. Fiqh Muamalat. Jakarta: Predana Media Group. 2010.

Ahmad Barozah. Tinjauan Hukum Islam terhadap Jual Beli Sperma Hewan Ternak di Desa Bigaran Borobudur magelang. Skripsi Thesis. UIN Sunan Kalijaga Yogyakarta. 2011.

Deni setiyono. Upah Mengupah Mengawinkan Hewan Ternak dalam Pandangan Imam Maliki dan Syafi'i (Studi Dusun 8 Desa Sendang Ayu Kec. Padang Ratu Kabupaten Lampung Tengah). Undergraduate Thesis. UIN Raden Intan Lampung. 2018.

Dwi Suwikyo. Kamus Lengkap Ekonomi Islam. Jakarta Selatan: PT. Buku Kita. 2009.

Enang Hidayat. Fiqh Jual Beli. Bandung: PT. Remaja Rosdakarya. 2015.

Feradis. Bioteknologi Reproduksi pada Ternak. Bandung: Alfabeta. 2010.

Helmi Karim. Fiqh Muamalah. Jakarta: PT. Raja Grafindo Persada. 1993.

Ija Suntana. Politik Ekonomi Islam Siyasah Maliyah. Bandung: Pustaka Setia. 2010. 
Masjfuk Zuhdi dan Masail Al-Fikiyah. Kapita Selekta Hukum Islam. Jakarta: Masagung. 1994.

Masjupri. Fiqh Muamalah 1. Surakarta: FSEI Publishing. 2013.

Mozes R. Toelihere. Inseminasi Buatan pada Ternak. Bandung: Angkasa. 1979.

Muhammad Amin Suma. Menggali Akar Mengurai Serat Ekonomi Dan Keuangan Islam, Jakarta: Kholam Publishing. 2008.

Muhammad Fuad Abdul Baqi. Terjemah Shahih Al-Bukhari (jilid 2). Jakarta: Pustaka As-Sunnah. 2010.

Rachmat Syafi'I. Fiqh Muamalah. Bandung: Pustaka Setia. 2001.

Sri Sudiarti. Fiqh Muamalah Kontemporer. Medan: FEBI UIN-SU Press. 2018.

Suardi Abbas. "Jual Beli Sperma dalam Perspektif Hukum Islam". https;//www.google.com/url?sa=t\&source=web\&rct=j\&url=https;// media.neliti.com

Sudarsono. Pokok-pokok Hukum Islam. Jakarta: PT. Rineka Cipta. 1993.

Sugiyono. Metode Penelitian Pendidikan. Bandung: Alfabeta. 2015.

Sulaiman Rasjid. Fiqh Islam. Bandung: Sinar Baru Algesindo. 1994.

Waluyo. Fiqih Muamalat. Yogyakarta: CV Gerbang Media Aksara, 2014. 